Testing Of Economic Convergence In The Middle Of The Covid-19 Pandemic

\author{
Samsul Arifin ${ }^{*}$, Sayifullah $^{2}$ \\ ${ }^{1,2}$ Economics Development, Sultan Ageng Tirtayasa University, Indonesia \\ *Email: samsularifin@untirta.ac.id
}

\begin{tabular}{|c|c|}
\hline Artikel Info & Abstrak \\
\hline $\begin{array}{l}\text { Article history: } \\
\text { Received March 12, } 2021 \\
\text { Revised May 16, } 2021 \\
\text { Accepted June 28, } 2021 \\
\text { Available online June 30, } 2021\end{array}$ & $\begin{array}{l}\text { This study aims to see whether the process of export } \\
\text { and import convergence occurs with the control } \\
\text { variable of the size of the country's economy affected } \\
\text { by the COVID- } 19 \text { pandemic as measured by GDP and } \\
\text { spatial interactions. The method of analysis in this }\end{array}$ \\
\hline $\begin{array}{l}\text { Keywords: } \\
\text { Convergence; Export-Import, } \\
\text { Dynamic Panel; Spatial Econometric. } \\
\text { JEL Classification; F14, C23, } \\
\text { E310 }\end{array}$ & $\begin{array}{l}\text { objects are } 64 \text { countries affected by the COVID-19 } \\
\text { pandemic-data taken in the period 2019q4-2020q3. } \\
\text { The results show that GDP and spatial elements } \\
\text { influence the process of export and import } \\
\text { convergence. The speed of convergence and the length } \\
\text { of time to reach a steady-state, imports are better than } \\
\text { exports reaching } 28-38 \% \text { with about one semester and } \\
\text { reaching } 15-16 \% \text { with a duration of } 1 \text { year (export } \\
\text { model). Exports and imports during the COVID-19 } \\
\text { pandemic reflect interactions between countries, with } \\
\text { distance as a determining factor. However, the role of } \\
\text { interaction between countries tends to be insignificant } \\
\text { in the long run. }\end{array}$ \\
\hline
\end{tabular}

\title{
INTRODUCTION
}

The SARS death rate of $10 \%$ and MERS of 35\% is much higher than the Corona Virus Disease 2019 (COVID-19) of 2\%. However, COVID-19 has a far more dangerous impact than SARS and MERS when viewed from economic issues and predicted to exceed the monetary or global financial crises. The immediate economic impact is the disruption of export and import performance due to the "lockdown" imposed in China and other countries. Therefore, the convergence of export and import performance can return to what it was before the economic crisis caused by COVID-19, becoming an important issue. Thus, economic convergence research is essential in answering this issue, especially by looking at the spatial effects of export and import performance in countries affected by COVID-19.

The literature on the impact of COVID-19 and the world economy has been widely discussed, such as economic waves: the effect of covid-19 on the world economy (Ruiz Estrada, 2020) and the global macroeconomic impacts of covid-19: seven scenarios (McKibbin \& Fernando, 2020). The two research results show that the economic recession caused by COVID-19 can affect the global economy across continents through disruption of the Chinese economy in the short term affecting the global economy. It that every $1 \%$ reduction in Chinese exports will decrease global export volume by around $0.01 \%$. It is based on China being the first country in the ten largest exporting countries globally and second in the ten largest importing countries in the world (Barua, 2020). Research related to convergence, such as Barro and Sala-I-Martin (1992) associated with the process of convergence (Yu \& Lee, 2012) and convergence 
conditional research (Islam, 2003). Econometric spatial approach research to describe spatial issues (Vayá-Valcarce \& Villar Frexedas, 2005).

Export and import performance with spatial elements explain economic convergence. One of the models is the Augmented Gravity Model adopting Newton's law of Gravitation by Tinbergen 1962 and Linneman (1966). (Chakravarty \& Chakrabarty, 2014). The convergence test refers to the Neoclassical Solow Growth model conducted by Barro and Sala-i-Martin (1992) and Islam (1995) as carried out by Yu and Lee (2012, p-3).

Research on economic convergence with spatial elements never has. Through the General Cliff-Ord SAR model and SEM application and development of Augmented Gravity theory, Newton's law of Gravity adoption model following the Neoclassical Solow Growth basic model as the final model for testing economic convergence (Exports and Imports) during the COVID-19 pandemic with a spatial econometric dynamic model of panel data. Our model differs from the existing literature in the following aspects. First, research conducted by Barro and Sala-I-Martin (1992); Islam (1995 and 2003); Yu and Lee (2012) is a study of the convergence of economic growth that does not use spatial elements and uses a basic model. Second, neoclassical Solow Growth research conducted by (Lall \& Yilmaz, 2001); (Paas, Kuusk, Schlitte, \& Võrk, 2007); (Önder, Karadag, \& Deliktas, 2007); (Schmtt \& Starke, 2011) examines the conditions of convergence by accommodating the structural characteristics of different countries.

Meanwhile, most of the econometric spatial research carried out is not up to the dynamic concept. It has not been able to carry out convergence testing in this research: Vayá-Valcarce and Villar Frexedas (2005) and (Ward \& Gleditsch, 2007). The spatial econometric approach is a test of economic convergence. This approach is to answer the research objectives and contribute to the empirical development of the spatial econometric application of dynamic panel data models. Spatial econometrics with dynamic panel data models is the General Cliff-Ord (1973) model, either the SAR or SEM models. (Irawan, 2018). According to the research objectives, the model is used to answer research questions to see whether export and import convergence occurs with the control variable of the size of the country's economy affected by the COVID-19 pandemic as measured by GDP and spatial interactions.

\section{RESEARCH METHODS}

This research aims to see the movement of goods (exports and imports) as a proxy for economic performance in the economic convergence model. Panel data can show the fundamental aspect of cross-country convergence, allowing unknown heterogeneity across countries and time effects. At the same time, distance is a spatial element indicating cross-country convergence. Thus, spatial econometrics is a solution for analyzing spatial interactions and structures and spatial dependencies between observations if it involves a "location" component. 
Table 1. Definition of Variables and Data Sources

\begin{tabular}{llc}
\hline \multicolumn{1}{c}{ Variables } & \multicolumn{1}{c}{ Definiton of Variables } & Source \\
\hline $\begin{array}{l}\text { National } \\
\text { Expome }\end{array}$ & $\begin{array}{l}\text { Gross Domestic Product, Nominal-Quarterly } \\
\text { and Domestic Currency } \\
\text { Goods, Value of Exports, Free on board, US } \\
\text { Dollars } \\
\text { Import }\end{array}$ & IFS \\
Foods, Value of Imports, Cost, Insurance, & IFS \\
\hline Note: & $\begin{array}{l}\text { The number of the cross-section was 64 countries in the period 2019q4-2020q3 } \\
\text { All variable data is logarithmic }\end{array}$
\end{tabular}

Research on economic convergence modeling by modifying Neoclassical Solow Growth conducted by Barro and Sala-i-Martin (1992), Islam (1995) and Yu and Lee (2012, p-3) uses the Augmented Gravity Adoption of Newton's Law of Gravity model from Tinbergen 1962 and Linneman (1966), explaining trade is a function of economies of scale or income and distance variables such as the model written by Roberts, (2004, p-341) and the Dynamic SAR model adapted from the General Cliff-Ord model. To get a spatial econometric model as follows:

Neoclassical Solow Growth Barro and Sala-i-Martin (1992), Islam (1995) and $\mathrm{Yu}$ and Lee (2012, p-3) with the convergence conditional model equation: $\ln y_{i, t}=\gamma \ln y_{i, t-1}+x_{i, t}^{\prime} \beta+\alpha_{i}+\eta_{t}+\varepsilon_{i, t}$

$\ln y_{i, t}$ is the logarithm of the dependent variable, $x_{i, t}^{\prime}$ The independent variable to accommodate the structural characteristics of different countries, gamma convergence by the significance of the parameter $\gamma$ (gamma) with the conditional structural elements of countries.

Augmented Gravity model;

$X_{i j}=\frac{Y_{i} E_{j}}{d_{i j}^{2}}$

$X_{i j}$ is the movement of goods and people between country i and country j, $Y_{i}$ is an economy of scale, $d_{i j}^{2}$ is geographic distance. Geographical distance becomes the spatial element information obtained from longitude $(x)$ and latitude (y), quantified to construct a spatial weight matrix based on the Minkowski/Euclidean/Manhattan metric formula. Alternate the inverse distance to create a $\mathrm{W}$ matrix that illustrates the involvement of the "location" component.

Dynamic SAR dan SDM adaptation model General Cliff-Ord:

$\operatorname{lny}_{\mathrm{it}}=\propto_{0}+\gamma \operatorname{lny}_{\mathrm{i}, \mathrm{t}-1}+\rho \mathrm{Wy}_{\mathrm{it}}+\Sigma \beta x_{i, t}^{\prime}+\tau \mathrm{W} x_{i, t}^{\prime}+\varphi_{\mathrm{t}}+\omega_{i}+\varepsilon_{\mathrm{it}}$,

SAR model

$$
\text { with } \varepsilon_{i t}=\lambda \mathrm{W}_{\varepsilon i t}+\mu_{\mathrm{it}}
$$

$\operatorname{lny}_{\mathrm{it}}=\propto_{0}+\gamma \operatorname{lny}_{\mathrm{i}, \mathrm{t}-1}+\rho \mathrm{Wy} \mathrm{y}_{\mathrm{it}}+\Sigma \beta x_{i, t}^{\prime}+\varphi_{\mathrm{t}}+\omega_{i}+\varepsilon_{\mathrm{it}}$,

$$
\text { with } \varepsilon_{\mathrm{it}}=\mu_{\mathrm{it}}
$$

SDM model

$$
\begin{aligned}
\ln \mathrm{y}_{\mathrm{it}} & =\alpha_{0}+\gamma \operatorname{lny} \mathrm{y}_{\mathrm{i}, \mathrm{t}-1}+\rho \mathrm{W} \mathrm{y}_{\mathrm{it}}+\Sigma \beta x_{i, t}^{\prime}+\tau \mathrm{W} x_{i, t}^{\prime}+\varphi_{\mathrm{t}}+\omega_{i}+\varepsilon_{\mathrm{it}}, \\
& \text { with } \varepsilon_{\mathrm{it}}=\mu_{\mathrm{it}}
\end{aligned}
$$


the spatial econometric dynamic panel data model can only be applied to the SAR model if $\lambda=0, \tau=0$ and SDM model if $\lambda=0$ where $\gamma=e^{-\theta T}$ With a value $0<\gamma<1$, convergence to the steady-state is direct and involves no oscillations. The intersection produces two indicators, namely, the speed test of the convergence rate and the half-life. How fast the convergence $\varnothing=-\ln (1+$ $\gamma) / T$ while the half-life $\tau_{h l}=-\ln (2) / \ln (1+\gamma / T)$ calculate time into a steadystate condition where $\mathrm{T}$ is the period $2019 \mathrm{q} 4-2020 \mathrm{q} 3$ or $\mathrm{T}$ is 4 (Paas, Kuusk, Schlitte, \& Võrk, 2007).

The model above describes three spatial interactions in the form of " $\rho$ " endogenous interaction with dependent variables, " $\tau$ " exogenous interaction between independent variables, " $\lambda$ " interaction between residuals (Elhorst, 2003). The dynamic model allows us to see the impact of the assumed shortrun on the three value equation $\gamma=0$ while the long-run effect thought $y_{t}=$ $y_{t-1}=y^{*}$ or value $\gamma \neq 0 . \beta$ is the explanatory variable parameter vector, $\mathrm{X}$ is the descriptive variable vector, $\mathrm{W}$ is the spatial matrix, it is the $\mathrm{i}$-th cross-section unit for the period to $-\mathrm{t}, \mu_{\mathrm{it}} \sim \mathrm{N}\left(0, \sigma^{2}\right)$ Usually is distributed error. $\omega_{i}$ and $\varphi_{\mathrm{t}}$ is constan across individuals unobservation fixed effect and effect time.

Based on equation 3, the estimation of the model with the $\mathrm{Y}$ variable being exports and imports to get a convergence model for exports and imports where the $\mathrm{X}$ variable is in the form of GDP. Equation 3 adopts Neoclassical Solow Growth, which reflects the convergence model of the economy with the adaptation of export and import variables and GDP and distance elements derived from the Augmented Gravity model. While the Dynamic SAR and HR adaptations of the General Cliff-Ord model as an econometric spatial estimate of the dynamic panel data model.

\section{RESULT AND DISCUSSION}

They were testing the presence or absence of convergence using gamma convergence. Proof of the conditional process of economic convergence with the control variable GDP and spatial elements, if the SDPD gamma parameter, GDP parameter, and W matrix parameters (spatial rho or $\mathrm{Wx}$ ) are significant. The gamma coefficient values calculate the speed of convergence and half-life to calculate the time to a steady-state condition.

The SDPD model must meet the identification requirements of the presence of spatial dependence on the regression equation. It that the model includes spatial details, so it must be estimated using IV-GMM or maximum likelihood. Testing the spatial element in the regression equation model contains spatial elements and pushes spatial cross-sectional independence in the OLS regression model panel using the test message. The results of the spatial effect test can result in table 2 .

\section{Table 2. Result of Test Spatial Effect}

\begin{tabular}{lcc}
\hline \multicolumn{1}{c}{ Coefficient } & Export Model & Import Model \\
\hline $\begin{array}{l}\text { Pesaran's test of cross sectional } \\
\text { independence: CD test }\end{array}$ & $38.842^{* * *}$ & $58.525^{* * *}$ \\
\hline
\end{tabular}

Notes: *, ** and *** indicate significance at the 5\%,10\% and $1 \%$ level

Ho: no spatial autocorrelation, if $\mathrm{p}$-value $<\mathrm{p}$-tab, reject Ho 
Tabel 3. Parameters Estimated in Spatial Dynamic Panel Data

\begin{tabular}{|c|c|c|c|c|}
\hline & $\begin{array}{l}\text { Export } \\
\text { Model }\end{array}$ & $\begin{array}{l}\text { Export } \\
\text { Model }\end{array}$ & $\begin{array}{l}\text { Import } \\
\text { Model }\end{array}$ & $\begin{array}{l}\text { Import } \\
\text { Model }\end{array}$ \\
\hline (SDPD) & SAR & SDM & SAR & SDM \\
\hline \multicolumn{5}{|l|}{ Main } \\
\hline L1 & $0.156 * * *$ & $0.168 * * *$ & $0.327^{* * *}$ & $0.460 * * *$ \\
\hline GDP & $0.689 * * *$ & $0.657 * * *$ & $0.509 * * *$ & $0.383 * * *$ \\
\hline Spatial rho & $0.191 * * *$ & $0.179 * * *$ & $0.213^{* * *}$ & $0.111^{* * *}$ \\
\hline $\begin{array}{l}\text { Variance: } \\
\text { sigma2_e }\end{array}$ & $0.003 * * *$ & $0.003 * * *$ & $0.002^{* * *}$ & $0.002^{* * *}$ \\
\hline Wx GDP & - & 0.062 & - & $0.368^{* * *}$ \\
\hline \multicolumn{5}{|l|}{ Statistic } \\
\hline 'r2 & 0.0094 & 0.0075 & 0.0107 & 0.0161 \\
\hline 'r2_w & 0.3080 & 0.3048 & 0.1207 & 0.3080 \\
\hline 'r2_b & 0.0094 & 0.0075 & 0.0107 & 0.0161 \\
\hline Obs & 192 & 192 & 192 & 192 \\
\hline Group & 64 & 64 & 64 & 64 \\
\hline Lenght & 3 & 3 & 3 & 3 \\
\hline
\end{tabular}

Notes: ${ }^{*}{ }^{* *}$ and ${ }^{* * *}$ indicate significance at the $5 \%, 10 \%$ and $1 \%$ level

Based on table 3 above, the estimation results of the export model show that the SDPD for SAR and HR direction signs of the estimation coefficients are not different from the size of the estimation parameters and the estimation results of the import model. In the export model, the GDP variable is significant and the results of the import model. The size of the economy indicated by GDP appears to have a more substantial influence on the performance of exports than imports. In this model, the spatial aspect by the interaction between the crosssections on the dependent variable (spatial rho) where the results are significant and the interaction between the cross-sections on the independent variable (Wx), specifically can be seen in the HR model although the export model is not adequate.

The gamma parameter indicated by L1 is significant, meaning that the convergence process occurs for both the export model and the import model. The speed of convergence and the half-life for exports is $(15-16 \%)$ with a halflife (4-5) quarterly or one-year period to reach a steady state. On the other hand, convergence speed gets $28-38 \%$ with a half-life of about 2-2.5 quarters for imports or one semester to reach a constant state.

The results of the dynamic model of SAR and HR can show changes in independent variables and direct impacts in region $\mathrm{i}$ and potential indirect effects on region $\mathrm{j}$ (other) both in the short and long term as indicated in SR and LR variables direct and indirect. That only direct SR is significant. Still, LR is not substantial for direct or indirect. That the impact of region i does not significantly affect region $\mathrm{j}$ (other) both in the long term, although in the short time, it looks significant when using the HR model. The results of the shortterm and long-term direct and indirect spatial estimation parameters can result in table 4. 


\begin{tabular}{ccccc} 
Table 4. Parameters for Estimating SAR and SDM dynamic Spatial \\
\multicolumn{6}{c}{ Econometric } & & & \\
\hline Variable & Export & Export & Import & Import \\
& Model & Model & Model & Model \\
\hline (SDPD) & SAR & SDM & SAR & SDM \\
SR_Direct & 0.7150525 & 0.67880358 & 0.42283536 & 0.40077012 \\
GDP & 0.0000 & 0.0000 & 0.0000 & 0.0000 \\
SR_Indirect & 1.1924686 & 1.1971699 & -2.7138768 & 0.97096351 \\
GDP & 0.1723 & 0.0370 & 0.9769 & 0.0000 \\
SR_Total & 1.9075211 & 1.8759735 & -2.2910415 & 1.9353635 \\
GDP & 0.0343 & 0.0012 & 0.9810 & 0.0000 \\
LR_Direct & 0.56912921 & 0.84085632 & 0.72775666 & 1.3286119 \\
GDP & 0.9352 & 0.0932 & 0.1917 & 0.8652 \\
LR_Indirect & -8.1528141 & 2.2896931 & -0.63795298 & 22.781467 \\
GDP & 0.9730 & 0.8911 & 0.9725 & 0.9327 \\
LR_Total & -7.5836849 & 3.1305494 & 0.08980368 & 24.110079 \\
GDP & 0.9756 & 0.8557 & 0.9962 & 0.9307 \\
\hline
\end{tabular}

The conditional process of export and import convergence occurs where GDP and country interaction by spatial cross-sectional independence is the determinant. However, the role of interaction between countries tends to be insignificant in the long run.

\section{DISCUSSION}

The export and import performance studied is the performance in 2019q42020q3. This periodization shows that amid the ongoing COVID-19 pandemic. Due to limited data availability, only 64 countries (cross-sections) as research areas; of course, all were countries with positive confirmation of COVID-19 with varying degrees of severity. In addition, of course, of the 64 countries studied, they also implement different policies related to implementing "lockdown" in responding to the spread of COVID-19; of course, this will impact the mobility of both people and goods including export and import activities.

The COVID-19 pandemic states a "lockdown" policy in stages with 14 days. If it was deemed necessary, it could be extended again for 14 days onwards. Implementing these policies is usually officially determined by the government where community activities are actually in limited conditions, such as economic activities, education, and daily routine activities of the community. Thus, the "lockdown" policy is carried out in 3 stages or less than 45 days.

Many countries have translated the situation returning to normal in China within three months into a tolerance limit for returning to activities even though handling the spread of the virus has not been entirely successful. The community must make peace with COVID-19, live side by side while still carrying out health protocols so that economic activities can return to running towards a new "new normal" life order. The term new normal is the most straightforward reason for every government to impose an easing of "lockdown" / PSBB / PPKM, which has implications for easing economic 
activity. The implementation of the new normal seems more to save the economy than the health aspect.

During the period 2019q4 to 2020q3 in countries affected by the COVID19 pandemic, export and import performance in 64 countries showed that countries experienced a very sharp decline. However, few countries were still able to maintain their performance. Therefore, an overview of export and import performance through net export information can result in Figure 1.

The net export deficit data for 2020q1-q3 is shown in figure 1.a. sequentially from the worst-hit countries: America, Britain, France, China, and Japan, where the majority are countries with a substantial contribution to the global economy. The net export deficit during 2020q1-2020q3 has a very diverse pattern depending on the country's export and import performance. The performance of China's exports and imports has decreased since 2020q1. However, in 2020q2, it has increased again because the portion of substances is still more significant than exports. Hence, net exports experience a different deficit for America, Britain, France, and Japan. Exports and imports decreased in 2020q1 - 2020q2 and increased in 2020q3 except for Japan. The majority of export and import performance in countries affected by the COVID-19 pandemic declined in 2020q1-q2 and grew in 2002q3. Still, several countries in 2020q2 had increased again, such as Argentina, Brazil, Kosovo, and Paraguay.

The behavior of declining export and import performance in 2020q1-q2 occurred in most countries affected not only in countries with net export deficits but also in countries with a net export surplus. Both experienced a relatively significant decline during the pandemic so that net exports were in excess. The net export surplus was not due to increasing exports or succeeding in reducing imports; however, exports were higher than imports in these countries. 


\section{Figure 1. Net Exports of 64 Countries Affected by COVID-19}

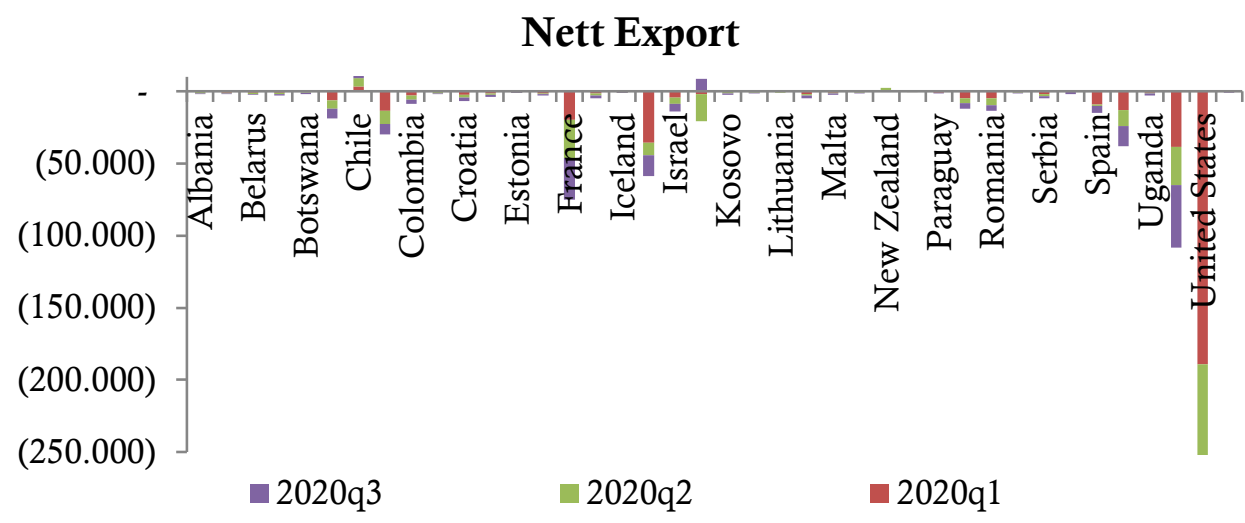

1.a. Countries with Net Export Deficits

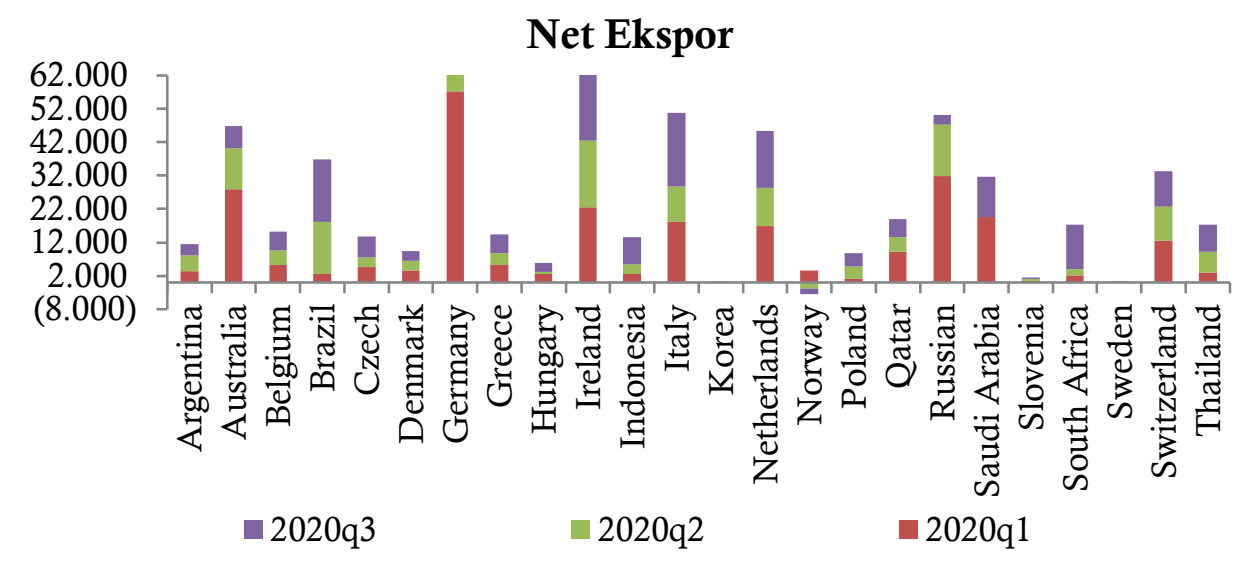

1.b. Countries with Net Export Surplus

The net export surplus data for 2020q1-q3 in figure 1.b. including Indonesia and Thailand, along with the countries with the most significant surpluses, respectively, namely Germany, Switzerland, Russia, Australia, and Italy. The decline in exports and imports occurred in 2020q1-q2 with a tendency of the same portion, so that net exports were still in a surplus position. This condition also appears in most countries affected by the COVID-19 pandemic, both in the case of a net export surplus or a net export deficit.

Based on these results, the net export surplus or deficit conditions that occurred in countries affected by the COVID-19 pandemic were more due to changes in export and import performance simultaneously with relatively the same magnitude, namely, a decline during the 2020q1-q2 period. If you look at the trend conditions in the first half of previous years, export and import performance declined in the 1st quarter and increased in the 2 nd quarter. In 2020q2, most countries' export and import performance affected by the COVID-19 pandemic declined due to the "lockdown" policy. However, China has increased because it has escaped the threat of COVID-19. In line with the spread of COVID-19 to global countries after March 2020.

The declining export-import performance during the COVID-19 pandemic was not only seen in 64 research object countries but almost all 
countries in the world. According to WTO estimates, world trade in 2020 will decrease by $13 \%$ (optimistic case) or by US\$ 2.5 trillion from a total of US\$ 17.8 trillion to $32 \%$ (worst case) or by US\$ 5.3 trillion due to the COVID-19 pandemic. The reason is mainly because of global supply chains that depend on China. When China's economy is slowing down, it impacts significant export destination partner countries such as America, Japan, Germany, the Netherlands, the UK, and Singapore, which are badly affected by COVID-19. Likewise, the most significant partners of China's import destination countries are in difficult times due to COVID-19, such as South Korea, Japan, America, Germany, and Australia (WTO, 2020). China's role in the global economy occupies $60 \%$ of world supply and demand (GDP), $65 \%$ of world manufacturing, and $41 \%$ of world manufacturing exports. About 20 percent of global trade in semifinished products comes from China. China is the second country with the largest GDP globally, being the first country in the ten largest exporting countries in the world and second in the ten largest importing countries in the world. In January and February 2020, China's import demand fell by $4 \%$, and exports fell $17.2 \%$. A more significant decline in import demand for non-essential goods by a considerable increase in imports of essential commodities. Every $1 \%$ reduction in Chinese exports will have the effect of decreasing global export volumes, amounting to about US\$2 billion or $0.01 \%$ (Barua, 2020).

Referring to table 2, every $1 \%$ decrease in GDP will cause a reduction in exports between $0.65-0.68 \%$, while a decline in imports from every $1 \%$ decrease in GDP variable is $0.3-0.5 \%$. The magnitude of the influence of each of these variables adjusts to the decline in global economic growth: China's economic downturn and a $4.8 \%$ decline in GDP (Gita Gopinath, 2020).

An illustration of the impact of the COVID-19 pandemic on the global economy impacts the estimated global GDP decline of $4.8 \%$ through a decrease in China's economic growth and globally. In the April 2020 edition of the World Economic Outlook report, the IMF estimates that China's 2020 growth will only be $1.2 \%$ from the previous estimate of $6.1 \%$. The majority of countries to experience contraction; Advanced Economies $-6.1 \%$ with the highest contraction Italy $-9.1 \%$, Spain -8\%, United Kingdom -6.5\%, United States $-5.9 \%$ and Japan $-5.2 \%$, Emerging Market and Developing Economies -1\%. Indonesia's growth is forecast to slow sharply to only $0.5 \%$. Emerging Asia and Developing Asia groups still grew positively by $1 \%$, and Low-Income Developing Countries grew $0.4 \%$ (Gita Gopinath, 2020). A decline in economic growth means a decrease in GDP and its constituent components, including exports and imports. In another version of the impact of the pandemic on global and regional growth presented by Warwick McKibbin and Roshen Fernando, the average GDP loss was 6.7\%, with a loss of $8.4 \%$ for the US and the euro area. (Baldwin \& Mauro, 2020).

\section{CONCLUSION}

The economic convergence (Export-Import model) test during the COVID-19 pandemic can use the SDPD model with the results showing a convergence process during the COVID-19 pandemic. Conditional convergence with GDP as a control variable in 64 countries. Observations show a convergence process with a speed of convergence. The length of time for 
achieving the import convergence process is much better than exports, which depends on each country with control over the size of its economy considering that there are vast countries. And progress, or territories or areas with a tendency to be small or even tiny countries.

The spatial interaction that occurs illustrates the spatial dependence between observations that only happens in the export and import variables but not for the GDP variable; this means that the country's exports or imports have conditions where statements at location $i$ are dependent (influenced) by other comments on the site. $j$, where $i \neq j$. Export and import performance during the COVID-19 pandemic are interrelated events between countries, depending on the distance between affected countries.

The policies taken to prevent the spread of COVID-19 have implications for economic aspects, including export and import activities. Export-import performance during the pandemic, apart from being dependent on GDP behavior, was also greatly influenced by the slowdown in the world economy and the existence of the Chinese economy, given its massive role in the global economy. The availability of data for countries affected by only 30\% (64 countries) of the 213 cross-sections affected by the pandemic is one aspect that is a weakness in this study.

\section{REFERENCES}

Baldwin, R., \& Mauro, B. W. di. (2020). Economics in the Time of COVID19. Centre for Economic Policy Research, 1-115. Retrieved from www.cepr.org

Barro, R. J., \& Sala-I-Martin, X. (1992). Convergence. Journal of Political Economy, 223-251. https://doi.org/10.1086/261816

Barua, S. (2020). COVID-19 pandemic and world trade : Some analytical notes, (April), 1-35.

Chakravarty, S. L., \& Chakrabarty, R. (2014). A Gravity Model Approach to Indo-ASEAN Trade-fluctuations and Swings. Procedia - Social and Behavioral Sciences, 133, 383-391. https://doi.org/10.1016/j.sbspro.2014.04.205

Elhorst, J. P. (2003). Specification And Estimation Of Spatial Panel Data Models. International Regional Science Review, 26(3), 244-268. https://doi.org/10.1007/978-3-642-40340-8

Gita Gopinath. (2020). World Economic Outlook, April 2020: The Great Lockdown. World Economic Outlook, IMF, (April), 1-5.

Irawan, T. (2018). Spatial econometrics dengan stata. IPB International Certified Training.

Islam, N. (2003). What have we learnt from the convergence debate? Journal of Economic Surveys, 17(3), 309-362. https://doi.org/10.1111/14676419.00197

Lall, S. V., \& Yilmaz, S. (2001). Regional economic convergence: Do policy instruments make a difference? The Annals of Regional Science, 35(1), 153166. https://doi.org/10.1007/s001680000035

McKibbin, W. J., \& Fernando, R. (2020). The Global Macroeconomic Impacts of COVID-19: Seven Scenarios. SSRN Electronic Journal, 1-38. 
https://doi.org/10.2139/ssrn.3547729

Önder, A., Karadag, M., \& Deliktas, E. (2007). The effects of public capital on regional convergence in Turkey. WP in Economics, (January), 1-25. Retrieved from http://www.iibf.ege.edu.tr/economics/papers/wp0701.pdf

Paas, T., Kuusk, A., Schlitte, F., \& Võrk, A. (2007). Econometric Analysis of Income Convergence in Selected EU Countries and Their Nuts 3 Level Regions. SSRN Electronic Journal, $1-20$. https://doi.org/10.2139/ssrn.1078863

Roberts, B. A. (2004). A gravity study of the proposed China-ASEAN free trade area. International Trade Journal, 18(4), 335-353. https://doi.org/10.1080/08853900490518208

Ruiz Estrada, M. A. (2020). Economic Waves: The Effect of the Wuhan COVID-19 on the World Economy (2019-2020). SSRN Electronic Journal, 1-10. https://doi.org/10.2139/ssrn.3545758

Schmtt, C., \& Starke, P. (2011). Explaining convergence of OECD welfare states: a conditional approach. Journal of European Social Policy, 21(2), 120135. https://doi.org/10.1177/0958928709XXXXXX

Vayá-Valcarce, E., \& Villar Frexedas, O. (2005). Financial contagion between economies: an Exploratory Spatial Analysis. Estudios de Economía Aplicada, 23(1), 151-166.

Ward, M., \& Gleditsch, K. (2007). An introduction to spatial regression models in the social science. Antimicrobial Agents and Chemotherapy, 58(12), 72507257. https://doi.org/10.1128/AAC.03728-14

WTO, P. R. (2020). Trade set to plunge as COVID-19 pandemic upends global economy.

Yu, Ji., \& Lee, L.-F. (2012). Convergence: A Spatial Dynamic Panel Data Approach. Global Journal of Economics, 01(01), 1-39. https://doi.org/10.1142/S2251361212500061 